\title{
Ameliorative Effect of Propolis Against Hepatorenal Alterations Induced by Methotrexate: Morphohistopathological Study
}

\author{
Efecto Protector del Propóleo en las Alteraciones Hepatorrenales \\ Inducidas por el Metotrexato: Estudio Morfohistopatológico
}

\author{
Mansour I. Almansour'; Yazun B. Jarrar²; Khalid A. Aloyaidy ${ }^{3}$ \& Bashir M. Jarrar ${ }^{4}$
}

ALMANSOUR, M. I.; JARRAR, Y. B.; ALOYAIDY, K. A. \& JARRAR, B. M. Ameliorative effect of propolis against hepatorenal alterations induced by methotrexate: morphohistopathological study. Int. J. Morphol., 35(2):756-764, 2017.

SUMMARY: Methotrexate (MTX) is widely used in the treatment of some forms of cancer but having severe side effects. The present work aimed to investigate the protective role of propolis treatment against alterations induced by MTX on the hepatic and renal tissues. Rabbits were exposed to MTX $(0.25 \mathrm{mg} / \mathrm{kg})$, with or without propolis $(50 \mathrm{mg} / \mathrm{kg})$ while hepatic and renal biopsies were examined for histological and histochemical abnormalities. Methotrexate induced hydropic degeneration, pyknosis, sinusoidal dilatation and bile duct hyperplasia in the liver together with renal tubular degeneration, glomerular shrinkage and hyaline droplet precipitation. While propolis partially ameliorated some of the morphometric and biochemical alterations, none of the hepatic alterations induced by MTX was protected by propolis treatment. Nevertheless glomerular shrinkage and renal tubule degeneration were partially protected in animals received both MTX plus propolis. It is concluded that propolis treatment has little or no ameliorative effect in protecting the hepatic and renal tissues from MTX toxicity.

KEY WORDS: Histological alterations; Kidney; Liver; Methotrexate toxicity; Propolis.

\section{INTRODUCTION}

Methotrexate is invested in treatment of several disorders including some types of malignancy (Bennett \& Brown, 2003; Watanabe et al., 2011). This drug inhibits DNA synthesis, slows down the growth of rapidly dividing cells and reduces the activity of several enzymes including dihydrofolic acid reductase. However, MTX is known to cause hepatotoxicity and renal damage by inducing oxidative stress and weakening the antioxidant defense (Novaes et al., 1996; van Ede et al., 1998; Hopwood \& Nyfors, 2004). Methotrexate was reported to induce hepatocytes fatty changes and sinusoidal lining cells, mild necrosis and inflammation (Maskaleris et al., 1998; Hemeida \& Mohafez, 2008). Several previous studies indicated that hematological, hepatic and renal toxicity are frequent with MTX treatment (Sotoudehmanesh et al., 2010; Gaies et al., 2012).

Propolis is natural resinous material of different plants consisting of many natural compounds and collected by honybees (Khalil, 2006; Valadares et al., 2008). This crude has been invested for long time by different nations in compacting many diseases due to its antioxidants content (Lee et al. 2000; Ota et al, 2001; de Almeida \& Menezes, 2002). In addition, propolis is being used as immune system stimulant agent due to its ability as free radicals scavenger (Urgur \& Arslan, 2004). Moreover, this natural product was reported to help in tissue regeneration and blood capillaries strengthening (Lejeune et al., 1988).

Propolis contribution as food and therapy supplement makes many people justify that this natural product can be used as supplement for cancer patients and can treat or prevent cancer (Galvao et al., 2007). It is not unusual to see patients using propolis and posting information about its ability in diseases fighting and cancer prevention (De Almeid \& Menezes 2002; Galvo et al., 2007; Li et al., 2010; ElMazoudy et al., 2011). In addition, some investigators intrigued by propolis potential to give better results in controlling the adverse effects of cancer therapy (Badr et al., 2011; Watanabe et al.). Caffeic acid phenethyl ester, an active ingredient of propolis could slow tumor growth by

\footnotetext{
${ }^{1}$ Department of Zoology, College of Science, King Saud University, Saudi Arabia.

${ }^{2}$ Department of Pharmacy, Faculty of Pharmacy, Al-Zaytoonah University of Jordan, Jordan.

${ }^{3}$ Biological Research Unit, Ministry of Education, Riyadh, Saudi Arabia.

${ }^{4}$ Department of Biological Sciences, College of Science, Jerash University, Jordan. 
singling networks that control the growth of the cancer cells in breast, bladder and prostate cancers (Chuu et al., 2012). Moreover, propolis flavonoids showed cytotoxic activity against fibrosarcoma and lung adenocarcinoma ( $\mathrm{Li}$ et al.). In addition, some studies reported that propolis could exert anticarcinogenic properties effects by immunomodulating action (Orsolic et al., 2005; Ozkul et al., 2006; Ishihara et al., 2009; Sforcin \& Bankova, 2011).

The present work was carried out to find out if propolis can ameliorate hepatorenal histological and histochemical alterations induced by MTX.

\section{MATERIAL AND METHOD}

Experimental Subjects. Thirty-two healthy adult male rabbits weighing 950-1050g, were used in the present study. The animals had free access to water and pellets.

Drugs. Methotrexate injections (Product of Ebewe Pharma, Austria) was invested in the present study.

Propolis. Commercial water soluble propolis crude in the form of capsules (1000 mg) manufactured by Marnys Spanish Company (Spain) and legally imported by Saudi Arabian Dug Store Ltd. (Saudi Arabia) was used. Its active ingredients were identified by the quality control of the manufacturer to contain the following: Phenolic acids (caffeic acid, tocopherol, sinapic acid, cinnamic acid, coumaric acid and ferulic acid) and flavonoids (quercetin, kaempferol, rutin and apigenin) together with amino acids and vitamins.

Propels dissolute was prepared immediately before use by dissolving capsules content in distilled water $(50 \mathrm{mg} / \mathrm{ml})$.

Experimental Protocol. Thirty-two rabbits were divided into four groups and were exposed to the used drugs as follows:

Group 1 (Control group): Each member of this group received a daily single i.m. injection of one $\mathrm{ml}$ normal saline for 35 days.

Group 2 (MTX group): Each member of this group received a daily single i.m. injection of MTX $(0.25 \mathrm{mg} / \mathrm{kg})$ for 35 days.

Group 3 (Propolis-MTX group): Each member of this group received a single a daily i.m. injection of MTX $(0.25 \mathrm{mg} / \mathrm{kg})$ plus oral dose of propolis $(50 \mathrm{mg} / \mathrm{kg}$ ) for 35 days.

Group 4 (Propolis only group): Each member of this group received daily $50 \mathrm{mg} / \mathrm{kg}$ propolis during the period of experimentation.
All experiments were carried out according to protocol approved by the ethical committee of King Saud University. Moreover, all animals were treated and handled according to the international guidelines for care and use of laboratory animals.

Morphometric Observation. Daily observation throughout the study was made for mortality, general well being and behavior patterns of all animals under study.

Body Weight Monitoring: The rabbits body weight was monitored at the beginning of treatment and after 35 days of treatment.

Percentage Absolute Liver Weight and Liver Index: Rabbits were euthanized and the liver together with the kidneys were taken from each rabbits immediately for the determination of the percentage absolute liver weight. The grade of change in the organ index induced by methotrexate doses was calculated according to the following equation:

Organ index $=$ Average weight of the experimental organs/ Average weight of the experimental animals

Weight of the control organs/weight of the control animals

Biochemical Analysis. Blood samples were collected from all rabbits under study. Serum was separated by centrifugation and were analyzed for the following biochemical parameters:aspartate aminotransferase (AST), alanine aminotransferase (ALT), total protein, and creatinine.

Histological Processing. Fresh portions from the right kidney including the cortex and medulla together with portions from the median lobe of the liver of each rabbit were taken and used for histological processing. Tissue processing was carried out by automatic Tissue Processor (Thermo Shandon Company). The samples were fixed in $10 \%$ neutral buffered formalin, dehydrated with ethanol, cleared with chloroform, wax impregnated, embedded and blocked with melted paraffin wax. Paraffin sections (4-5 $\mu \mathrm{m})$ from all experimental rabbits of all groups were applied for hematoxylin and eosin $(\mathrm{H} \& \mathrm{E})$ stain together with some special stains (Jarrar \& Taib, 2008). Stained histological sections were tested and viewed for histological abnormalities in the hepatic and renal tissues of all rabbits used in the present study.

Statistical Analysis. Statistical analysis was done by using independent t-test and the results of the morphometric and biochemical analysis were expressed by the average $\pm \mathrm{sd}$. The $\mathrm{p}$-value $<0.05$ was considered statistically significant. 


\section{RESULTS}

No mortality occurred in any of the experimental groups of the present study. In comparison with the control animals, rabbits exposed to MTX $(0.25 \mathrm{mg} / \mathrm{kg})$ for 35 days demonstrated diarrhea, reddening of the skin, dark urine and tarry fecal matter.

Morphometric Alterations. Alterations in the body weight of rabbit exposed to MTX for 35 days are seen in Table I. One may observe that MTX exposure affected significantly ( $\mathrm{p}$ value $<0.05$ ) the body weight gain, while propolis administration didn't influence the body weight gain. On the other hand, animals subjected to MTX treatment only did not demonstrate body weight gain.
The liver average weight and the percentage absolute liver weight to control one together with the change in the liver index are seen on Table II. There was no significant difference ( $p$ value $>0.05$ ) in the liver and kidney index between MTX, propolis and the control group.

Biochemical Alteration. As seen in Table III and in comparison with the control rabbits and the ones exposed to propolis only, MTX treatment for 35 days lowered total proteins but elevated creatinine, AST and ALT ( $\mathrm{p}$ value < 0.001-0.05). Levels of ASL, ALT and creatinine were higher in MTX plus propolis rabbits than the control ones. Moreover, ASL, ALT in rabbits exposed to MTX plus propolis were less significant ( $\mathrm{p}$ value $<0.05$ ) in comparison with those treated with MTX only where partial amelioration was demonstrated by propolis combination with the drug.

Table I. Change on the average body weight ( $\mathrm{g}$ ) of rabbits subjected to overdoses of MTX for 35 days.

\begin{tabular}{lccc}
\hline Dose & Starting Weight & Weight after 35 days & P-value \\
\hline Control group (Normal saline) & $1068 \pm 98$ & $1217 \pm 112$ & $* 013$ \\
Received MTX $0.25 \mathrm{mg} / \mathrm{kg})$ ) & $1077 \pm 109$ & $1042 \pm 114$ & 0.54 \\
Received MTX and propolis $(0.25 \mathrm{mg} / \mathrm{kg} \mathrm{MTX,} 50 \mathrm{mg} / \mathrm{kg}$ propolis ) & $1082 \pm 119$ & $1074 \pm 117$ & 0.89 \\
Received propolis only (50 mg/kg) & $1093 \pm 122$ & $1242 \pm 118$ & $* 0.026$ \\
\hline
\end{tabular}

“*” Represents statistically significant (p-value $<0.05)$ using student $\mathrm{t}$ test.

Table II. Change on the relative ratio of liver and kidneys weight to body weight of rabbits subjected to overdoses of MTX for 35 days.

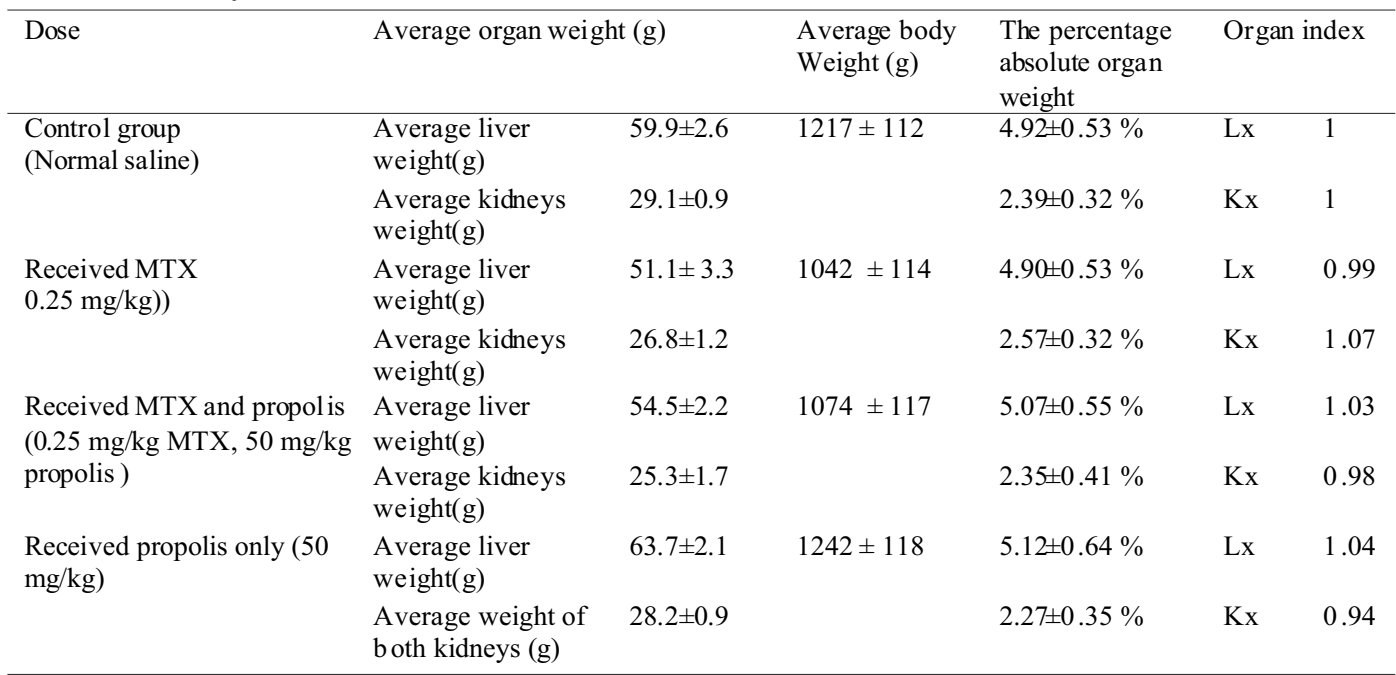

Table III. Biochemical analysis of the rabbits under study.

\begin{tabular}{lcccc}
\hline Biochemical test & Control rabbits & Rabbits received MTX & $\begin{array}{c}\text { Rabbits received } \\
\text { MTX plus propolis }\end{array}$ & $\begin{array}{c}\text { Rabbits received } \\
\text { propolis }\end{array}$ \\
\hline AST (IU/l) & $23.4 \pm 4.4$ & $* * * 70.5 \pm 9.7$ & $\dagger^{*} 36.3 \pm 5.2$ & $18.8 \pm 2.8$ \\
ALT & $11.4 \pm 2.9$ & $33.8 \pm 6.7 * * *$ & $* 19.3 \pm 4.7 \dagger$ & $9.07 \pm 1.9$ \\
Total Protein $(\mathrm{g} / \mathrm{dl})$ & $8.6 \pm 1.05$ & $* * * 4.58 \pm 0.65$ & $7.2 \pm 0.76$ & $8.37 \pm 0.97$ \\
Creatinine $(\mathrm{mg} / \mathrm{dl})$ & $0.54 \pm 0.11$ & $* * * 1.73 \pm 0.26$ & $1.42 \pm 0.19 * *$ & $0.62 \pm 0.12$ \\
\hline
\end{tabular}

"*","**" and "***" represent statistically significant p-value $<0.05,<0.01$ and $<0.001$, respectively, in comparison with control group.

$" \dagger "$ represents statistically significant $\mathrm{p}$-value $<0.05$, in comparison with the MTX group. 
Hepatic Histological Alteration. Examination of the hepatic tissues of all rabbits used in the present study showed the followings:

Liver of the Control Rabbits. All members of the control group demonstrated normal hepatic structures concerning the hepatocytes, lobules architecture and the portal spaces (Fig. 1 a-b).

Liver of Rabbits Treated with MTX. The following abnormalities were seen in the hepatic tissues of rabbits exposed to MTX $(0.25 \mathrm{mg} / \mathrm{kg})$ for 35 days:
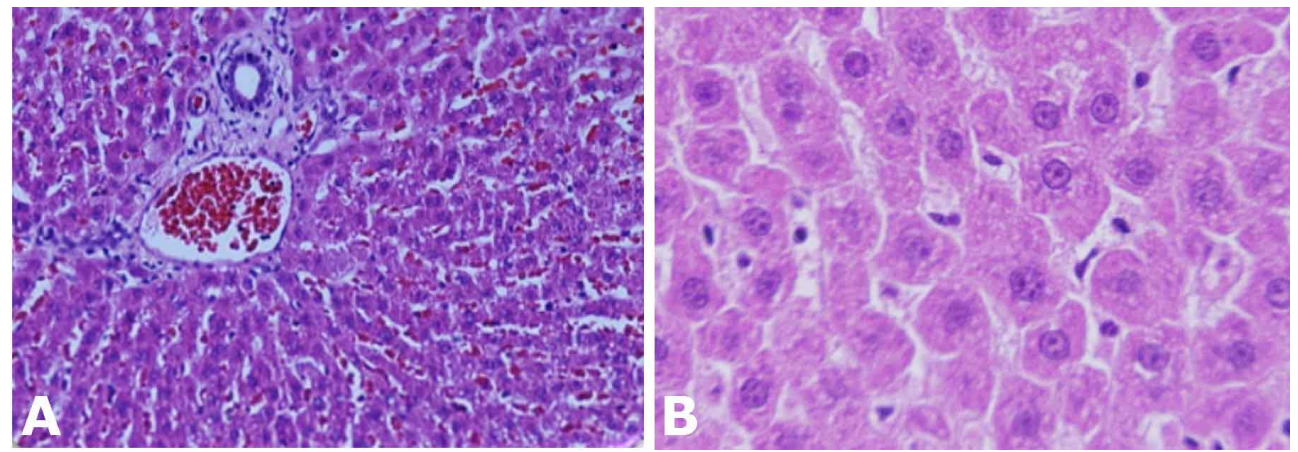

Fig. 1. Microphotograph sections in the liver of control rabbits demonstrating: (a) Normal hepatic architecture (b) Normal hepatocytes.
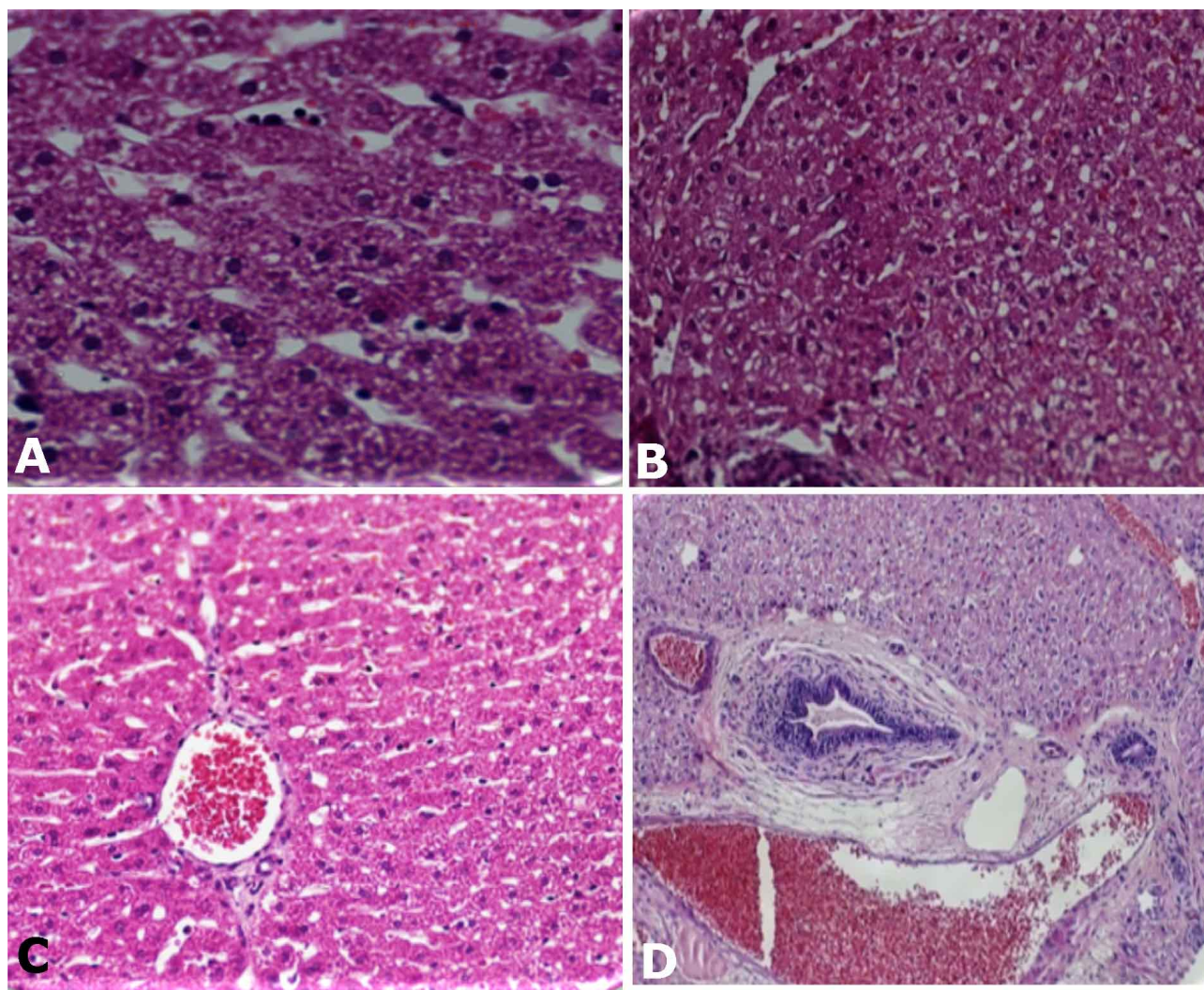

Fig. 2. Microphotograph sections in the liver of rabbits treated with MTX $(0.25 \mathrm{mg} /$ kg) demonstrating: (a) Hepatocyte cytoplasmic vacuolation together with pyknotic hepatocytes, H\&E stain. (b) Hepatocytes hydropic degeneration, H\&E stain. (c) Sinusoidal dilatation and pyknosis, H\&E stain. (d) Bile duct hyperplasia and proliferation, H\&E stain. 
Karyopyknosis: Some hepatocytes showed condensed nuclei with irregular nuclear margin (Fig. 2c).

Bile Duct Hyperplasia: Hyperplasia and proliferation was identified in the bile ducts of all members of MTX treated rabbits (Fig. 2d).

\section{Liver of Rabbits Treated with MTX Plus Propolis}

The following abnormalities were detected in the liver of rabbits treated with MTX $(0.25 \mathrm{mg} / \mathrm{kg})$ plus propolis $(50$ $\mathrm{mg} / \mathrm{kg}$ ) for 5 weeks.

Hydropic Degeneration: The hepatocytes of the rabbits received MTX plus propolis showed almost hydropic degenerative cytoplasmic vacuolation similar to that seen in the animals received MTX only (Fig. 3a).

Karyopyknosis: The hepatocytes of this group of rabbits showed no protection from pyknosis that was seen in the hepatocytes of rabbits treated with MTX only (Fig. 3b).
Bile Duct Proliferation: Proliferation and hyperplasia of the bile duct together with peribiliary mononuclear inflammatory aggregation was observed in the liver of this group of rabbits. Less sinusoidal dilatation was seen in the rabbits of this group in comparison with the liver of animals received MTX only (Fig. 3c).

Liver of Rabbits Treated with Propolis Only. The hepatic lobular architecture and zonal accentuation of rabbits subjected to propolis $(50 \mathrm{mg} / \mathrm{kg})$ only were well preserved and kept intact and demonstrated normal hepatocytes, sinusoids and hepatic portal triads (Fig. 4).

\section{Renal Histological Alterations}

Kidneys of the Control Rabbits. Both cortex and medulla of the control rabbits kidneys showed normal glomeruli together with normal proximal and distal renal tubules (Fig. 5a-b). Loops of Henli and the collecting tubules also showed normal pattern.
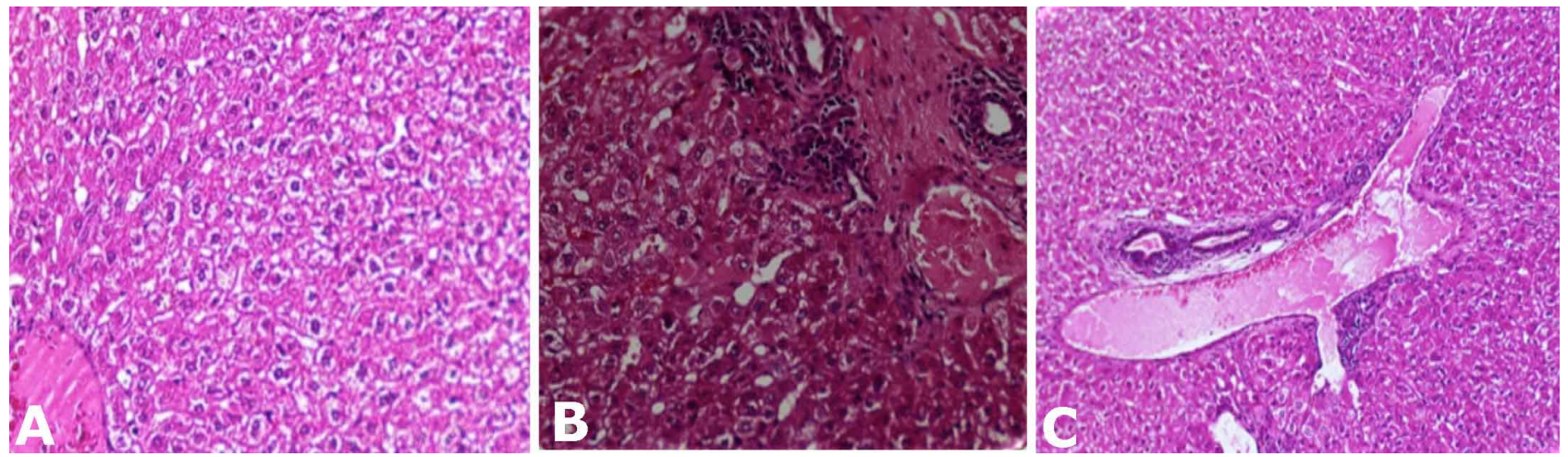

Fig. 3. Microphotograph of sections in the liver of rabbits treated with MTX $(0.25 \mathrm{mg} / \mathrm{kg}$ ) plus propolis (50 mg/kg) demonstrating: (a) Hydropic degeneration, H\&E stain. (b) Karyopyknosis and cytoplasmic vacuolation, H\&E stain. (c) Hyperplasia of the bile duct and proliferation together with peribiliary mononuclear inflammatory aggregation, H\&E stain.

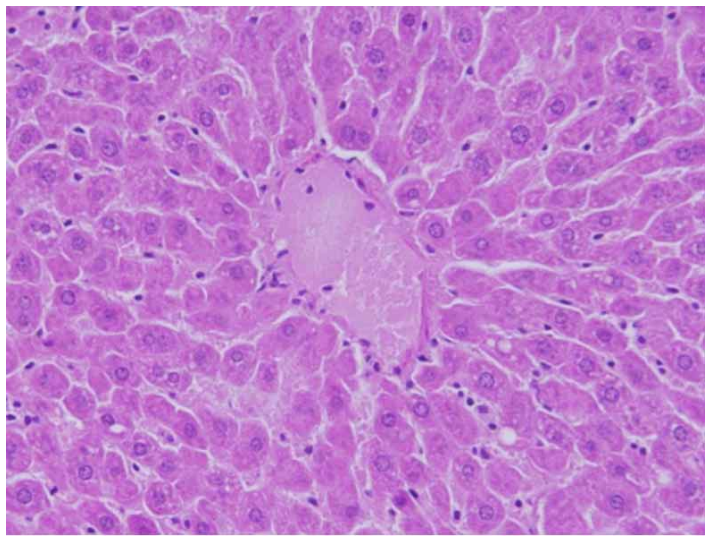

Fig. 4. Microphotograph of section in the liver of rabbit subjected to propolis demonstrating normal lobular architecture and normal hepatocytes, H\&E stain.

\section{Kidneys of Rabbits Exposed to MTX}

Rabbits received MTX $(0.25 \mathrm{mg} / \mathrm{kg})$ for 5 weeks showed the following renal histological abnormalities:

Glomerular Shrinkage: Glomerular atrophy was visible in renal tissue of rabbits of this group where the shrunken tuft occupied small portion of Bowman's space (Fig. 6a).

Renal tubular Degeneration: Renal tubules mild degeneration was demonstrated with proximal tubules were more affected than the distal ones (Fig. 6b).

Hyaline Droplets Precipitation: Hyaline droplets formation was visible in the epithelial lining of some distal nephritic tubules (Fig. 6c). 

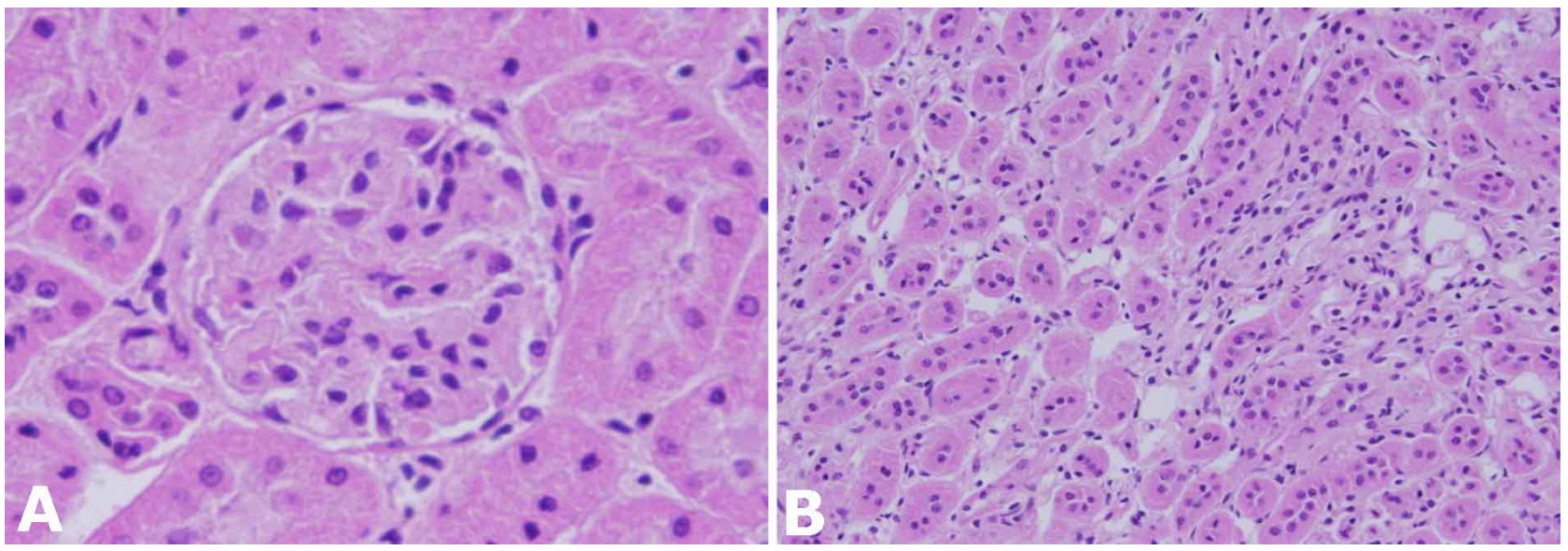

Fig. 5. Microphotograph sections in the kidney of control rabbits demonstrating: (a) Normal glomerular and normal interstitial tissues, H\&E stain. (b) Normal renal tubules, H\&E stain.
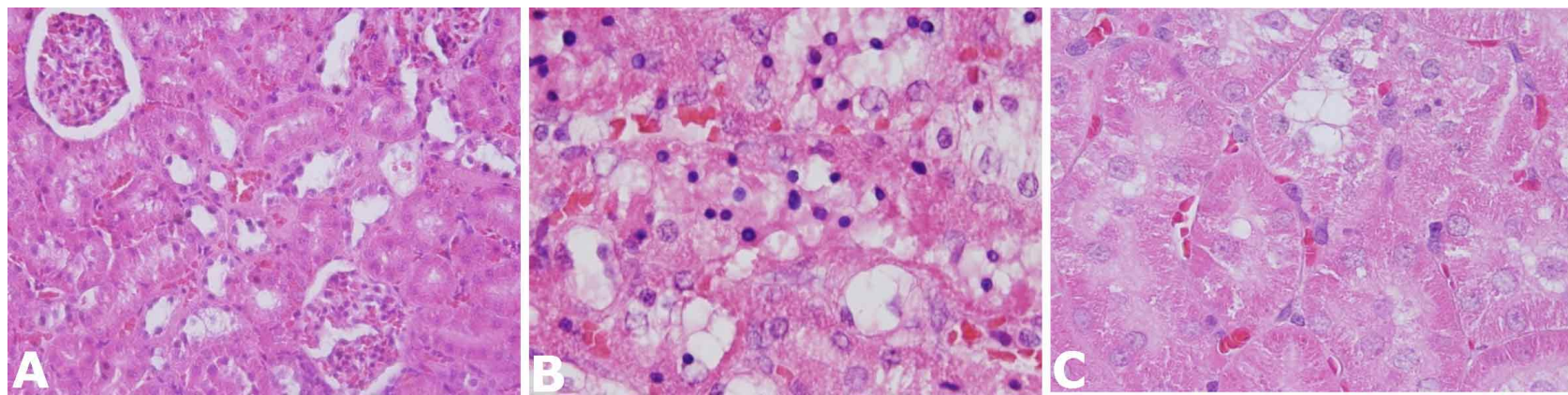

Fig. 6. Microphotograph of sections in the kidney of rabbits treated with MTX showing: (a) Shrinkage of glomerular tuft with renal degeneration, H\&E stain. (b)Tubular necrosis, H\&E stain. (c) Hyaline droplets formation, H\&E stain.

Kidneys of Rabbits Treated with MTX Plus Propolis. Less prominent glomerular shrinkage was demonstrated in the kidneys of this group of rabbits in comparison with those treated with only MTX (Fig. 7a). Prominent renal tubules necrosis and degeneration were also observed in the renal tissues of this group (Fig. 7b).
Kidneys of Rabbits Treated with Propolis Only. No glomerular, tubular or interstitial alterations were seen in the renal tissues of rabbits received propolis $(50 \mathrm{mg} / \mathrm{kg}$ ) for 5 weeks (Fig. 8).
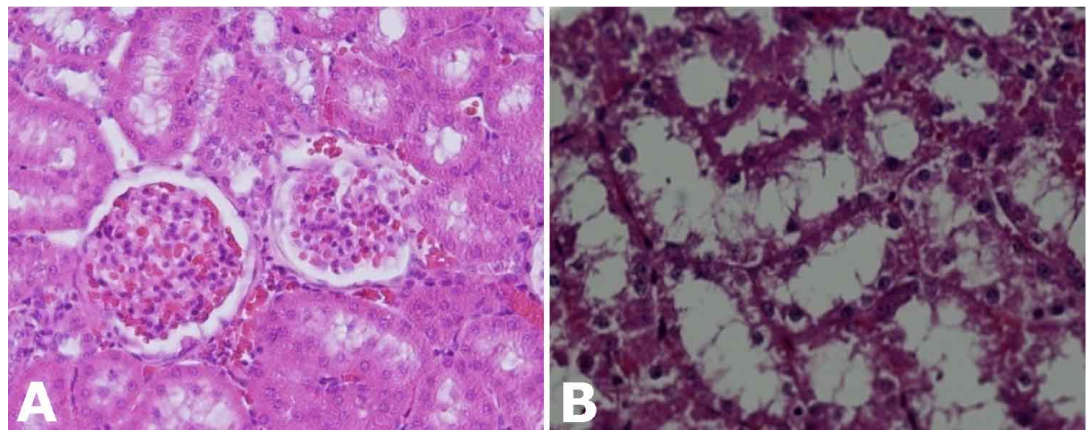

Fig. 7. Microphotograph of sections in the kidney of rabbits treated with MTX plus propolis exhibiting: (a) Mild glomerular shrinkage, H\&E stain. (b) Tubular degeneration and necrosis, H\&E stain.

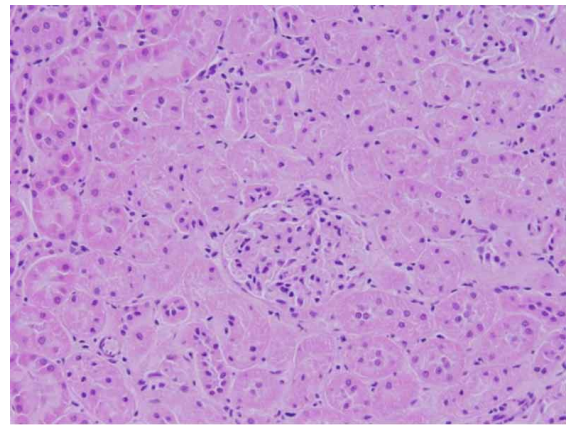

Fig. 8. Microphotograph of section in the kidney of rabbit treated with propolis only exhibiting normal glomerular, tubular and interstitial tissues, H\&E stain. 


\section{DISCUSSION}

Methotrexate is used in the treatment of several malignancies and inflammatory disorders (Badr et al.; Gais et al., 2012). This chemotherapeutic agent can suppress DNA synthesis by inhibiting dihydrofolate reductase, the key role player in methionine and purine synthesis (Galivan, 1980; Gaies et al.). However, it was found that MTX could cause oxidative stress in hepatic and renal tissues (van Ede et al.; Walker et al., 2000).

The morphometric findings of the present work showed a decline in body weight due to MTX exposure while propolis failed to ameliorate this alteration. This might indicate an oxidative stress on the pathway of the metabolic enzymes and the immunological status induced by MTX while propolis showed no protective amelioration from these alterations.

The findings of the present investigation indicated that MTX treatment lowered total proteins but elevated creatinine, AST and ALT. The concentration of the liver enzymes ALT and AST is used as an indicator for liver functions and in detecting hepatocytes injury, while ALT is primarily released during liver damage and hepatocellular necrosis (Singh et al, 2011). In addition, blood total proteins concentration is often reduced slightly during hepatocellular damage (Thapa \& Walia, 2007; Singh et al.). Furthermore, elevation of creatinine level indicates a deficiency in the filtering function of the kidney. The findings of this study showed that propolis combination with MTX reduced significantly the elevation in AST and ALT and normalized significantly the total protein level. Moreover, propolis showed little amelioration to creatinine level induced by MTX but failed to reach statistical significant ( $p$ value $>0.05$ ). These biochemical findings may indicate that propolis could partially ameliorate the biochemical alterations induced by MTX.

The findings of the present study showed that MTX could induce hepatic hydropic degeneration, pyknosis, sinusoidal dilatation and bile duct hyperplasia together with renal tubular degeneration, glomerular shrinkage and hyaline droplet precipitation. Some of these alterations were reported by other investigators where Roenigk et al. (1988) observed hepatorenal fatty infiltration, nuclear changes, inflammation and necrosis. The induced histopathological alterations might be resulted from folate stores depletion, one of the main side effect of MTX in the hepatic tissues. In addition, the seen renal tubular degeneration induced by MTX might be resulted from precipitation of this drug and its metabolites in the epithelial lining of the tubules due to their relatively insolubility in acidic urine (Donehower et al., 1979; Smeland et al., 1996).

The results of the present study indicated that the severity in the liver damage and to lesser extent in the renal tissues of rabbits exposed to MTX plus propolis were still evident. This may indicate that the protective activity of propolis could not compensate the toxicity induced by MTX in the hepatic and renal tissues. Some investigations indicated that propolis could exhibit hepatoprotective effects by protecting mitochondria against oxidative damage (Guimarães et al., 2012).

Propolis contains a group of antioxidants including flavonoids, phenolic acid esters, terpenes, cinnamic acid and others. The antioxidant activity of propolis showed evidences of protective role against oxidative stress caused by free radicals oxidative stress under normal conditions. Propolis exhibits capability of combating against lipid peroxidation that can impair cellular structure and functions due to its scavenging free radicals protection role (Bergamini et al., 2004; Yousef \& Salama, 2009). This crude can also activate superoxide dismutase and catalase that have capability against free radicals (Jasprica et al., 2007). Some previous studies found that the phenolic contents of propolis had an ability to inhibit membrane free radical formation (Russo et al., 2006; Kanbur et al., 2009). The results of the present work indicated that propolis could not protect the renal tissue from injury induced by MTX. Some studies reported that the antioxidant properties of propolis could involve in the protection of renal tissues from damage by some toxicants (Conde de la Rosa et al., 2006). In addition, some reports indicated that propolis has therapeutic potential and protective role against the toxicity of several chemical compounds such as aluminum chloride and environmental pollutants (Sarabia et al., 2009; Yousef \& Salama; Yousef et al., 2010; El-Mazoudy et al.). Moreover, propolis was reported to ameliorate the MTX-induced ilium injury and biochemical alterations towards normal and showed slight protection in the hepatorenal histological alterations induced by MTX during treatment of Ehrlich carcinoma (Badr et al.; Abdul-Hamid \& Salah, 2016). In addition, propolis extract was found to have protective effect against doxorubicin and cypermethrin induced toxicity (Eraslan et al., 2008; Singla et al., 2014). Furthermore, some previous studies reported an inhibitory activity to the crude of Egyptian propolis (El-khawaga et al., 2003). 


\section{CONCLUSION}

One can conclude from the finding of the present study that bee propolis has little or no ameliorative role in modulating the hepatic and renal injury induced by MTX toxicity.

\section{ACKNOWLEDGEMENTS}

The authors would like to extend their sincere appreciation to the Deanship of Scientific Research at King Saud University for its funding this Research project (RG 1435-040).

ALMANSOUR, M. I.; JARRAR, Y. B.; ALOYAIDY, K. A. \& JARRAR, B. M. Efecto protector del propóleo en las alteraciones hepatorrenales inducidas por el metotrexato: estudio morfohistopatológico. Int. J. Morphol., 35(2):756-764, 2017.

RESUMEN: El metotrexato (MTX) es ampliamente utilizado en el tratamiento de algunas formas de cáncer, pero tiene efectos secundarios graves. El presente trabajo tuvo como objetivo investigar el papel protector del tratamiento con própoleo frente a las alteraciones inducidas por el MTX en los tejidos hepático y renal. Se expusieron conejos a MTX $(0,25 \mathrm{mg} / \mathrm{kg})$, en grupos con y sin propóleo (50 mg / kg), y se realizaron biopsias hepáticas y renales, que fueron examinadas buscando anomalías histológicas e histoquímicas. El metotrexato indujo la degeneración hidrópica, picnosis, dilatación sinusoidal e hiperplasia del conducto biliar en el hígado, junto con la degeneración tubular renal, la contracción glomerular y la precipitación hialina. Mientras que el propóleo parcialmente mejoró algunas de las alteraciones morfométricas y bioquímicas, ninguna de las alteraciones hepáticas inducidas por MTX fue protegido por el tratamiento con propóleo. Sin embargo, la contracción glomerular y la degeneración de los túbulos renales fueron parcialmente protegidos en animales que recibieron MTX más propóleo. Se concluye que el tratamiento con propóleo tiene poco o ningún efecto mejorador en la protección de los tejidos hepáticos y renales sometidos a la toxicidad de MTX.

PALABRAS CLAVE: Alteraciones histológicas; Riñón; Hígado; Toxicidad del metotrexato; Propóleos.

\section{REFERENCES}

Abdul-Hamid, M. \& Salah, M. Intervention of ginger or propolis ameliorates methotrexate-induced ileum toxicity. Toxicol. Ind. Health., 32(2):31322, 2016.

Badr, M. O. T.; Edress, N. M. M.; Abdallah, A. A. M.; Hashem, M. A.; ElDeen, N. A. M. N.; Neamat-Allah, A. N. F. \& Ismail, H. T. H. Propolis protects against methotrexate induced hepatorenal dysfunctions during treatment of Ehrlich carcinoma. J. Am. Sci., 7(12):313-9, 2011.

Bennett, P. N. \& Brown, M. J. Clinical Pharmacology. 9th ed. London,Churchill Livingston, 2003.

Bergamini, C. M.; Gambetti, S.; Dondi, A. \& Cervellati, C. Oxygen, reactive oxygen species and tissue damage. Curr. Pharm. Des., 10(14):1611-26, 2004.

Chuu, C. P.; Lin, H. P.; Ciaccio, M. F.; Kokontis, J. M.; Hause, R. J. Jr.; Hiipakka, R. A.; Liao, S. \& Jones, R. B. Caffeic acid phenethyl ester suppresses the proliferation of human prostate cancer cells through inhibition of p70S6K and Akt signaling networks. Cancer Prev. Res. (Phila.), 5(5):788-97, 2012.

Conde de la Rosa, L.; Schoemaker, M. H.; Vrenken, T. E.; Buist-Homan, M.; Havinga, R.; Jansen, P. L. \& Moshage, H. Superoxide anions and hydrogen peroxide induce hepatocyte death by different mechanisms: involvement of JNK and ERK MAP kinases. J. Hepatol., 44(5):918-29, 2006.

de Almeida, E. C. \& Menezes, H. Anti-inflammatory activity of propolis extracts: A review. J. Venom. Anim. Toxins, 8(2):191-212, 2002.

Donehower, R. C.; Hande, K. R.; Drake, J. C. \& Chabner, B. A. Presence of 2,4-diamino-N10-methylpteroic acid after high-dose methotrexate. Clin. Pharmacol. Ther, 26(1):63-72, 1979.

El-Mazoudy, R. H.; Attia, A. A. \& El-Shenawy, N. S. Protective role of propolis against reproductive toxicity of chlorpyrifos in male rats. Pestic. Biochem. Physiol., 101(3):175-81, 2011.

El-khawaga, O. A.; Salem, T. A. \& Elshal, M. F. Protective role of Egyptian propolis against tumor in mice. Clin. Chim. Acta, 338(1-2):11-6, 2003.

Eraslan, G.: Kanbur, M.; Silici, S.; Altinordulu, S. \& Karabacak, M. Effecs of cypermethrin on some biochemical changes in rats: the protective role of propolis. Exp. Anim., 57(5):453-60, 2008.

Gaies, E.; Jebabli, N.; Trabelsi, S.; Salouage, I.; Charfi, R.; Lakhal, M. \& Klouz, A. Methotrexate side effects: review article. J. Drug Metab. Toxicol. 3(4):1-5, 2012.

Galivan, J. Evidence for the cytotoxic activity of polyglutamate derivatives of methotrexate. Mol. Pharmacol., 17(1):105-10, 1980.

Galvao, J.; Abreu, J. A.; Cruz, T.; Machado, G. A. S.; Niraldo, P. Daugsch, A.; Moraes, C. S.; Fort, P. \& Park, Y. K. Biological therapy using propolis as nutritional supplement in cancer treatment. Int. J. Cancer Res., 3(1):4353, 2007.

Guimarães, N. S.; Mello, J. C.; Paiva, J. S.; Bueno, P. C.; Berretta, A. A.; Torquato, R. J.; Nantes, I. L. \& Rodrigues, T. Baccharis dracunculifolia, the main source of green propolis, exhibits potent antioxidant activity and prevents oxidative mitochondrial damage. Food Chem. Toxicol., 50(34):1091-7, 2012

Hemeida, R. A. \& Mohafez, O. M. Curcumin attenuates methotraxate-induced hepatic oxidative damage in rats. J. Egypt Natl. Canc. Inst., 20(2):141-8, 2008.

Hopwood, D. \& Nyfors, A. Effect of methotrexate therapy in psoriatics on the Ito cells in liver biopsies, assessed by point-counting. J. Clin. Pathol., 29(8):698-703, 2004.

Ishihara, M.; Naoi, K.; Hashita, M.; Itoh, Y. \& Suzui, M. Growth inhibitory activity of ethanol extracts of Chinese and Brazilian propolis in four human colon carcinoma cell lines. Oncol. Rep., 22(2):349-54, 2009.

Jarrar, B. M. \& Taib, N. T. Histocytochemistry. 3rd ed. Riyadh, King Saud University Press, 2008.

Jasprica, I.; Mornar, A.; Debeljak, Z.; Smolcic-Bubalo, A.; Medic-Saric, M.; Mayer, L.; Romic, Z.; Bucan, K.; Balog, T.; Sobocanec, S. \& Sverko, V. In vivo study of propolis supplementation effects on antioxidative status and red blood cells. J. Ethnopharmacol., 110(3):548-54, 2007.

Kanbur, M.; Eraslan, G. \& Silici, S. Antioxidant effect of propolis against exposure to propetamphos in rats. Ecotoxicol. Environ. Saf., 72(3):90015, 2009.

Lejeune, B.; Pourrat, A. \& Dehmouche, H. Propolis use in dermatocosmetology. Parfum. Cosmet. Aromes, 82(1):73-7, 1988.

Lee, Y. J.; Liao, P. H.; Chen, W. K. \& Yang, C. Y. Preferential cytotoxicity of caffeic acid phenethyl ester analogues on oral cancer cells. Cancer Lett., 153(1-2):51-6, 2000. 
Li, F.; Awale, S.; Tezuka, Y. \& Kadota, S. Cytotoxicity of constituents from Mexican propolis against a panel of six different cancer cell lines. Nat. Prod. Commun., 5(10):1601-6, 2010

Khalil, M. L. Biological activity of bee propolis in health and disease. Asian Pac. J. Cancer Prev., 7(1):22-31, 2006.

Maskaleris, T.; Lialiaris, T. \& Triantaphyllidis, C. Induction of cytogenetic damage in human lymphocytes in vitro and of antineoplastic effects in Ehrlich ascites tumor cells in vivo treated by methotrexate, hyperthermia and/or caffeine. Mutat. Res., 422(2):229-36, 1998.

Novaes, G. S.; Mello, S. B.; Laurindo, I. M. \& Cossermelli, W. Low dose methotrexate decreases intraarticular prostaglandin and interleukin 1 levels in antigen induced arthritis in rabbits. J. Rheumatol., 23(12):20927, 1996.

Orsolic, N.; Sver, L.; Terzic', S. \& Basic', I. Peroral application of watersoluble derivative of propolis (WSDP) and its related polyphenolic compounds and their influence on immunological and antitumour activity. Vet. Res. Commun., 29(7):575-93, 2005.

Ota, C.; Unterkircher, C.; Fantinato, V. \& Shimizu, M. T. Antifungal activity of propolis on different species of Candida. Mycoses, 44(9-10):375-8, 2001.

Ozkul, Y.; Eroglu, H. E. \& Ok, E. Genotoxic potential of Turkish propolis in peripheral blood lymphocytes. Pharmazie, 61(7):638-40, 2006.

Roenigk, H. H. Jr.; Auerbach, R.; Maibach, H. I. \& Weinstein, G. D. Methotrexate in psoriasis: revised guidelines. J. Am. Acad. Dermatol., 19(1 Pt. 1):145-56, 1988

Russo, A.; Troncoso, N.; Sanchez, F.; Garbarino, J. A. \& Vanella, A. Propolis protects human spermatozoa from DNA damage caused by benzo[a]pyrene and exogenous reactive oxygen species. Life Sci., 78(13):1401-6, 2006.

Sarabia, L.; Maurer, I. \& Bustos-Obregón, E. Melatonin prevents damage elicited by the organophosphorous pesticide diazinon on mouse sperm DNA. Ecotoxicol. Environ. Saf., 72(2):663-8, 2009.

Singh, A.; Bhat, T. K. \& Sharma, O. P. Clinical biochemistry and hepatotoxicity. J. Clin. Toxicol., S4:001, 2011. doi:10.4172/21610495.S4-001

Singla, S.; Kumar, N. R. \& Kaur, J. In vivo studies on the protective effect of propolis on doxorubicin-induced toxicity in liver of male rats. Toxicol. Int., 21(2):191-5, 2014.

Sforcin, J. M. \& Bankova V. Propolis: is there a potential for the development of new drugs? J. Ethnopharmacol., 133(2):253-60, 2011.

Smeland, E.; Fuskevåg, O. M.; Nymann, K.; Svendesn, J. S.; Olsen, R.; Lindal, S.; Bremnes, R. M. \& Aarbakke, J. High-dose 7hydromethotrexate: acute toxicity and lethality in a rat model. Cancer Chemother. Pharmacol., 37(5):415-22, 1996.

Sotoudehmanesh, R.; Anvari, B.; Akhlaghi, M.; Shahraeeni, S. \& Kolahdoozan, S. Methotrexate hepatotoxicity in patients with rheumatoid arthritis. Middle East. J. Dig. Dis., 2(2):104-9,2010.

Thapa, B. R. \& Walia, A. Liver function tests and their interpretation. Indian J. Pediatr., 74(7):663-71, 2007.

Urgur, A. \& Arslan, T. An in vitro study on antimicrobial activity of propolis from Mugla province of Turkey. J. Med. Food., 7(1):90-4, 2004.

Valadares, B. L.; Graf, U. \& Spanó, M. A. Inhibitory effects of water extract of propolis on doxorubicin-induced somatic mutation and recombination in Drosophila melanogaster. Food Chem. Toxicol., 46(3):1103-10, 2008.

van Ede, A. E.; Laan, R. F.; Blom, H. J.; De Abreu, R. A. \& van de Putte, L. B. Methotrexate in rheumatoid arthritis: an update with focus on mechanisms involved in toxicity. Semin. Arthritis Rheum., 27(5):27792, 1998.

Walker, T. M.; Rhodes, P. C. \& Westmoreland, C. The differential cytotoxicity of methotrexate in rat hepatocyte monolayer and spheroid cultures. Toxicol. In Vitro, 14(5):475-85, 2000.

Watanabe, M. A.; Amarante, M. K.; Conti, B. J. \& Sforcin. J. M. Cytotoxic constituents of propolis inducing anticancer effects: a review. J. Pharm. Pharmacol., 63(11):1378-86, 2011.

Yousef, M. I.; Kamel, K. I.; Hassan, M. S. \& El-Morsy, A. M. Protective role of propolis against reproductive toxicity of triphenyltin in male rabbits. Food Chem. Toxicol., 48(7):1846-52, 2010.

Yousef, M. I. \& Salama, A. F. Propolis protection from reproductive toxicity caused by aluminium chloride in male rats. Food Chem. Toxicol., 47(6):1168-75, 2009.

\author{
Corresponding author: \\ Prof. Bashir M. Jarrar \\ Department of Biological Sciences \\ College of Science \\ Jerash University \\ Jerash 26150 \\ JORDAN
}

\section{E-mail: bashirjarrar@yahoo.com}

Received: 15-09-2016

Accepted: 16-03-2017 